Original Article

\title{
EVALUATION OF THE QUALITY OF DIFFERENT BRANDS OF ASCORBIC ACID IN FREETOWN, SIERRA LEONE
}

\author{
MICHAEL LAHAI ${ }^{1 *}$, EUGENE B. S. CONTEH ${ }^{1}$, AMINATA FREDERICA MANSARAY ${ }^{1}$, JOSEPH AMARA ${ }^{1}$, MOHAMED \\ BAWOH $^{1}$, JAMES P. KOMEH ${ }^{1}$, ALPHAN TEJAN-KELLA ${ }^{1}$, MOHAMED SESAY ${ }^{1}$, WILTSHIRE C. N. JOHNSON
}

Faculty of Pharmaceutical Sciences, College of Medicine and Allied Health Sciences, University of Sierra Leone, Freetown, 00232, Sierra Leone Email: miclahisaac@gmail.com

Received: 01 Feb 2021, Revised and Accepted: 30 Jul 2021

ABSTRACT

Objective: This study evaluates the registration status and the quality of nine brands of Vitamin C sold in Freetown, Sierra Leone, using official and non-official methods of analysis.

Methods: The parameters taken into consideration during the study include non-official methods (friability and disintegration) and the official methods (identification test, uniformity of dosage unit, and assay by titrimetric and colorimetric tests). The different brands of vitamin $\mathrm{C}$ were selected and classified as registered and unregistered based on the data derived from the National Medicines Regulatory Authority.

Results: One vitamin C product collected was unregistered at the National medicines regulatory authority (Pharmacy Board of Sierra Leone). All nine vitamin $\mathrm{C}$ products met the requirements for uniformity of dosage unit. The vitamin $\mathrm{C}$ products also conformed to the BP specification for friability and identification test (retention factor). The identification test showed that each brand contained vitamin $\mathrm{C}$ (ascorbic acid). The disintegration test was not applicable for chewable tablets. Three of the four non-chewable vitamin $\mathrm{C}$ products complied with the BP specification for disintegration, while one failed and did not meet the requirement. The assay results for ascorbic acid using titration and colourimetric method were comparable and appropriate for determining vitamin C. Out of a total of nine samples; seven met the requirement for BP specification (Passed) for assay. In contrast, one product did not meet the BP requirement (failed), and one sample had more vitamin $\mathrm{C}$ than the Pharmacopoeia limit.

Conclusion: Periodic quality evaluation and routine checks for pharmaceutical products can ascertain the quality of products, their storage conditions and identify potential counterfeit medications.

Keywords: Post-market surveillance, Quality control, Vitamin C, Counterfeit, Quality assurance, Unregistered

(C) 2021 The Authors. Published by Innovare Academic Sciences Pvt Ltd. This is an open-access article under the CC BY license (https://creativecommons.org/licenses/by/4.0/) DOI: https://dx.doi.org/10.22159/ijpps.2021v13i9.41230. Journal homepage: https://innovareacademics.in/journals/index.php/ijpps.

\section{INTRODUCTION}

Vitamin C or L-ascorbate is a water-soluble vitamin. It is a vital antioxidant that plays an essential role in human nutrition [1]. It acts as a cofactor for some biologically active radicals. Vitamin $\mathrm{C}$ is necessary for building blood vessels, ligaments, tendons, bones and is also essential in synthesising carnitine, which is involved in metabolism in most plants and some bacteria $[1,2]$

WHO suggested that most drugs in the world today are either falsified or substandard and that $10 \%$ are from low and middleincome countries. Substandard medicines may come from poor manufacturing and quality assurance processes and reach the public due to lax control measures, whereas falsified medicines are deliberately and fraudulently labelled [3].

Ascorbic acid degrades in the presence of enzymes and atmospheric oxygen [4]. Vitamin C bears an obvious similarity with hexose sugars; hence it is conceivable that the molecule might serve as a carbon source for respiration or bacteria growth that might be fermented [5] Storage condition of low temperature and humidity retards microbial growth whereby chemical and biological processes are slowed down [6]. However, breaching the protective barrier by microbial growth results in the subsequent destruction of the commodity.

An excellent quality control system can create the platform for employers and employees to develop a fantastic working atmosphere and efficiency resulting from improved wellbeing and quality of life achieved by preventing absence from work and reducing hospital stay. This study adds to research evidence in Sierra Leone and the African region by providing information for researchers and the public on the quality of vitamin $\mathrm{C}$ products circulating in Sierra Leone. It also includes rudimentary information on the registration status of the sampled vitamin $\mathrm{C}$ products.

\section{MATERIALS AND METHODS}

\section{Experimental design}

The convenience sampling of nine (9) brands of vitamin C, purchased and collected from Pharmacies in Freetown from the 20th February to the 22nd March 2019 and stored using the recommendations on each label claim. The physicochemical analysis at the National Pharmaceutical Quality Control Laboratory of the Pharmacy Board of Sierra Leone, New England Ville, Freetown, took place from the 20th to the 2nd June 2019.

Test solution, solvent, and reagents

0.1M Ammonium cerium (IV) Sulphate, $1 \mathrm{M} \mathrm{H}_{2} \mathrm{SO}_{4}$, water, ferroin solution, ethanol, ferricyanide solution.

\section{Instrument used}

The instrument includes Analytical balance, volumetric Flask, friabulator, vernier calliper, filter paper, separating funnel, pipette, mortar, pestle, weighing boat, timer, measuring cylinder, burette, burette stand, UV lamp, UV apparatus, Thin layer chromatography chamber, Thin layer Chromatography plate, chromatogram.

\section{Test methods used}

\section{Active substance identification test}

Thin Layer Chromatography Identification: Thin layer Chromatogram of pure vitamin C $(0.5 \%)$ in water and equivalents solutions of tablets obtained with Ethanol-EtOH: Water- $\mathrm{H}_{2} \mathrm{O}(6: 1)$ as a solvent system using their $\mathrm{R}_{\mathrm{f}}$ values and colour characteristics under ultraviolet light $[2,7]$

Uniformity of dosage units

Weighed ten tablets individually using an analytical balance. The weight of the ten (10) tablets is determined to calculate the average 
weight. The assay value for each tablet was determined using the average weight. The acceptance criteria were determined using the method in the British Pharmacopoeia 2018 [7].

\section{Disintegration test}

The requirement for disintegration does not apply to Chewable Ascorbic Acid Tablet. One dosage unit was placed in each of the basket's six tubes and added a disc. The apparatus, operated using the specified medium of $37^{\circ} \mathrm{C}$ as the immersion fluid. The time taken for each of the four tablets of each brand to disintegrate was recorded [7].

\section{Friability}

Twenty tablets were weighed and subjected to abrasion for $4 \mathrm{~min}$ at $100 \mathrm{rev} / \mathrm{min}$ using Erweka single drum friability tester. The end of the revolution was then followed by reweighing the twenty tablets to calculate the percentage loss.

If cracked, cleaved, or broken tablets are present in the tablet sample after tumbling, it fails the test. If the results are difficult to interpret or the weight loss is greater than the targeted value, the test procedure was rechecked and repeated, and the mean of three tests, determined. A maximum weight loss (obtained from a single test or the average of three tests) of not more than $1.0 \%$ is considered acceptable for most products.
For each brand of Vitamin C tablets, a tablet sample was carefully dusted, weighed (W1), and placed in the friabulator at $100 \mathrm{rpm}$ (rounds per minute) for four minutes. At the end of the four minutes, the tablets are removed from the drum, dusted, and accurately weighed for the second time (W2) [7]

Percentage of Friability of ascorbic acid was determined using the formula below:

$$
\text { Percentage Friability }=\left(\frac{\text { Initial weight }(\mathrm{W} 1)-\text { Final weight }(\mathrm{W} 2)}{\text { Initial weight }(\mathrm{W} 1)}\right) \times 100
$$

\section{Assay by titrimetry}

Twenty tablets are weighed together and powdered. A quantity containing $0.15 \mathrm{~g}$ of ascorbic acid was dissolved in a mixture of $30 \mathrm{ml}$ of water and $20 \mathrm{ml}$ of $1 \mathrm{M}$ Sulphuric acid and titrated with $0.1 \mathrm{M}$ Ammonium Cerium (IV) Sulphate, using ferroin solution as the indicator [7].

\section{Assay by colourimetric method}

The absorbance of the coloured complex formed between potassium ferricyanide solution and ascorbic acid measured at $520 \mathrm{~nm}$ was used to plot a calibration curve against the concentration of ascorbic acid $(2.5-25 \mathrm{ug} / \mathrm{ml}\}$. The amount of ascorbic acid was determined using the regression equation from the calibration curve [2].

\section{RESULTS}

\section{Profile of vitamin $\mathrm{c}$ tablets}

Table 1: Sample profile of products this describes each sample based on their packaging, manufacturing country, storage condition and label claim

\begin{tabular}{|c|c|c|c|c|c|c|c|}
\hline $\begin{array}{l}\text { Sample } \\
\text { code }\end{array}$ & $\begin{array}{l}\text { Product } \\
\text { description }\end{array}$ & Primary package & $\begin{array}{l}\text { Secondary } \\
\text { package }\end{array}$ & $\begin{array}{l}\text { Manufacturing } \\
\text { country }\end{array}$ & Storage condition & $\begin{array}{l}\text { Label } \\
\text { claim }\end{array}$ & $\begin{array}{l}\text { Registration } \\
\text { status }\end{array}$ \\
\hline 001 & $\begin{array}{l}\text { Orange cylindrical } \\
\text { tablet with a line on } \\
\text { the centre of one } \\
\text { side }\end{array}$ & $\begin{array}{l}\text { Thermoformed } \\
\text { aluminium blister } \\
\text { pack of } 10 \text { tabs }\end{array}$ & $\begin{array}{l}\text { Red and } \\
\text { green card } \\
\text { box }\end{array}$ & India & $\begin{array}{l}\text { Store at temperature } \\
\text { below } 25^{\circ} \mathrm{C} \text { protected } \\
\text { from light and } \\
\text { moisture }\end{array}$ & $100 \mathrm{mg}$ & Registered \\
\hline 002 & $\begin{array}{l}\text { Orange flavour oval } \\
\text { tablets }\end{array}$ & $\begin{array}{l}\text { Orange and white } \\
\text { Plastic container }\end{array}$ & $\begin{array}{l}\text { Orange and } \\
\text { white Plastic } \\
\text { container }\end{array}$ & $\begin{array}{l}\text { United } \\
\text { Kingdom }\end{array}$ & $\begin{array}{l}\text { Store in a cool, dry } \\
\text { place }\end{array}$ & $500 \mathrm{mg}$ & Registered \\
\hline 003 & $\begin{array}{l}\text { Orange cylindrical } \\
\text { tablet with a line on } \\
\text { the centre of one } \\
\text { side with an } \\
\text { inscription (ECL) }\end{array}$ & $\begin{array}{l}\text { Thermoformed } \\
\text { aluminium blister } \\
\text { pack }\end{array}$ & $\begin{array}{l}\text { Orange and } \\
\text { green } \\
\text { rectangular } \\
\text { card box }\end{array}$ & Nigeria & $\begin{array}{l}\text { Store in a cool, dry } \\
\text { place below } 30^{\circ} \mathrm{C}\end{array}$ & $100 \mathrm{mg}$ & Registered \\
\hline 004 & $\begin{array}{l}\text { Orange cylindrical } \\
\text { tablet with an } \\
\text { inscription }\end{array}$ & $\begin{array}{l}\text { Thermoformed } \\
\text { aluminium strip } \\
\text { pack }\end{array}$ & $\begin{array}{l}\text { Orange and } \\
\text { green card } \\
\text { box }\end{array}$ & Nigeria & $\begin{array}{l}\text { Store in a cool, dry } \\
\text { place protected from } \\
\text { light }\end{array}$ & $100 \mathrm{mg}$ & Registered \\
\hline 005 & $\begin{array}{l}\text { Brown cylindrical } \\
\text { tablet }\end{array}$ & $\begin{array}{l}\text { Orange white, and } \\
\text { blue plastic } \\
\text { container }\end{array}$ & $\begin{array}{l}\text { Orange } \\
\text { white, and } \\
\text { blue plastic } \\
\text { container }\end{array}$ & USA & $\begin{array}{l}\text { Store at room } \\
\text { temperature, tightly } \\
\text { closed }\end{array}$ & $500 \mathrm{mg}$ & Registered \\
\hline 006 & $\begin{array}{l}\text { Yellow cylindrical } \\
\text { tablet with a line on } \\
\text { the centre of one } \\
\text { side }\end{array}$ & $\begin{array}{l}\text { Orange white, and } \\
\text { blue plastic } \\
\text { container }\end{array}$ & $\begin{array}{l}\text { Orange and } \\
\text { grey plastic } \\
\text { container }\end{array}$ & China & $\begin{array}{l}\text { Store in a cool, dry } \\
\text { place. Keep out of } \\
\text { reach of children }\end{array}$ & $100 \mathrm{mg}$ & Registered \\
\hline 007 & $\begin{array}{l}\text { Lemon yellow } \\
\text { cylindrical tablet }\end{array}$ & $\begin{array}{l}\text { Green and white } \\
\text { plastic container }\end{array}$ & $\begin{array}{l}\text { Green and } \\
\text { white plastic } \\
\text { container }\end{array}$ & China & $\begin{array}{l}\text { Store in a cool, dry } \\
\text { place below } 30^{\circ} \mathrm{C}\end{array}$ & $250 \mathrm{mg}$ & Unregistered \\
\hline 008 & $\begin{array}{l}\text { Orange cylindrical } \\
\text { tablet }\end{array}$ & $\begin{array}{l}\text { Green and orange } \\
\text { plastic container }\end{array}$ & $\begin{array}{l}\text { Green and } \\
\text { orange } \\
\text { plastic } \\
\text { container }\end{array}$ & Nigeria & $\begin{array}{l}\text { Store in a cool and dry } \\
\text { place }\end{array}$ & $100 \mathrm{mg}$ & Registered \\
\hline 009 & $\begin{array}{l}\text { Orange and brown } \\
\text { tablets }\end{array}$ & $\begin{array}{l}\text { Thermoformed } \\
\text { aluminium blister } \\
\text { packs }\end{array}$ & $\begin{array}{l}\text { Green and } \\
\text { yellow card } \\
\text { box }\end{array}$ & Nigeria & $\begin{array}{l}\text { Store in a cool, dry } \\
\text { place below } 25^{\circ} \mathrm{C} . \\
\text { Protect from light and } \\
\text { moisture and keep out } \\
\text { of reach of children. }\end{array}$ & $100 \mathrm{mg}$ & Unregistered \\
\hline
\end{tabular}


Mean, standard deviation and acceptance value of vitamin $\mathrm{C}$

Table 2: Uniformity of dosage units this shows the deviation and acceptance value for each sample of ascorbic acid tablets. Sample 002 did not meet the requirement for acceptance value

\begin{tabular}{|c|c|c|c|c|c|c|}
\hline Sample & Mean \pm SD1 & $\begin{array}{l}\text { Calculated } \\
\text { acceptance value } 1\end{array}$ & $\begin{array}{l}\text { Acceptance } \\
\text { limits (L1) }\end{array}$ & Mean \pm SD2 & $\begin{array}{l}\text { Calculated } \\
\text { acceptance value } 2\end{array}$ & $\begin{array}{l}\text { Acceptance limit(L2); lower, } \\
\text { upper limit }\end{array}$ \\
\hline 001 & $106.3 \pm 1.70$ & 8.84 & $\leq 15$ & NA & NA & NA \\
\hline 002 & $115.1 \pm 1.03$ & 16.04 & $\leq 15$ & $115.06 \pm 0.81$ & 15.18 & $\leq 25 ; 86.30,143.83$ \\
\hline 003 & $100.9 \pm 0.48$ & 1.72 & $\leq 15$ & NA & NA & NA \\
\hline 004 & $101.6 \pm 1.80$ & 4.48 & $\leq 15$ & NA & NA & NA \\
\hline 005 & $102.7 \pm 1.78$ & 5.418 & $\leq 15$ & NA & NA & NA \\
\hline 006 & $100.4 \pm 2.32$ & 6.698 & $\leq 15$ & NA & NA & NA \\
\hline 007 & $100.2 \pm 1.30$ & 3.742 & $\leq 15$ & NA & NA & NA \\
\hline 008 & $52.6 \pm 1.09$ & 2.568 & $\leq 15$ & NA & NA & NA \\
\hline 009 & $101.5 \pm 3.48$ & 9.623 & $\leq 15$ & NA & NA & NA \\
\hline
\end{tabular}

NA: Not Applicable; ne (number of experiments for each sample) = 10; SD = standard deviation

Identification and friability test for vitamin $c$

Table 2: Identification and Friability test for vitamin $C$ the samples showed the same retention factor ( $\left.R_{f}\right)$ for each brand of ascorbic acid. Friability percentage calculated to determine the physical strength of compressed and uncoated tablets showed that each tablet had less than $1 \%$ breakage

\begin{tabular}{|c|c|c|}
\hline Sample & Friability (\%) \pm SD & $R_{\mathrm{f}}$ Values \\
\hline 001 & $99.85 \pm 0.01$ & 0.7 \\
\hline 002 & $99.75 \pm 0.05$ & 0.7 \\
\hline 003 & $99.73 \pm 0.05$ & 0.7 \\
\hline 004 & $99.69 \pm 0.07$ & 0.7 \\
\hline 005 & $100 \pm 0.35$ & 0.7 \\
\hline 006 & $99.91 \pm 0.02$ & 0.7 \\
\hline 007 & $98.2 \pm 0.30$ & 0.7 \\
\hline 008 & $99.30 \pm 0.05$ & 0.7 \\
\hline 009 & $99.62 \pm 0.03$ & 0.7 \\
\hline
\end{tabular}

NA: Not Applicable; ne (number of experiments for each sample) = 3; SD = standard deviation

Disintegration test for vitamin C

Table 3: Disintegration test for non-chewable vitamin C tablet, the requirement for disintegration does not apply to chewable tablets. All samples tested met the requirement for disintegration, while sample 003 did not comply with the requirement for disintegration as per the British pharmacopoeia

\begin{tabular}{lll}
\hline Sample code & Time (min) & Limit \\
\hline 001 & NA & Not Applicable for Chewable Tablets \\
002 & 30 & Not Applicable for Chewable Tablets \\
003 & NA & $<15$ min \\
004 & NA & Not Applicable for Chewable Tablets \\
005 & NA & Not Applicable for Chewable Tablets \\
006 & 5 & Not Applicable for Chewable Tablets \\
007 & 6 & $<15$ min \\
008 & 7 & $<15$ min \\
009 & 715 min \\
\hline
\end{tabular}

NA: Not applicable

Assay of vitamin C

Table 4: Assay of vitamin C tablet, six samples $(003,004,005,006,007$, and 009$)$ met the requirement for $B P$ pharmacopoeia, while two samples (001 and 002) recorded more significant quantities of vitamin $C$ for one or both quality control analysis (titrimetry and colourimetry) and one sample (008) failed quality control analysis

\begin{tabular}{|c|c|c|c|}
\hline Sample code & Titration value (\%) & Colorimetric (\%) & Limit (\%) \\
\hline 001 & 106.27 & 110.00 & $95.00-107.50$ \\
\hline 002 & 115.07 & $>125.00$ & $95.00-107.50$ \\
\hline 003 & 100.74 & 95.00 & $95.00-107.50$ \\
\hline 004 & 101.56 & 100.00 & $95.00-107.50$ \\
\hline 005 & 103.40 & 106.25 & $95.00-107.50$ \\
\hline 006 & 100.13 & 100.00 & $95.00-107.50$ \\
\hline 007 & 100.74 & 103.75 & $95.00-107.50$ \\
\hline 008 & 52.42 & 47.50 & $95.00-107.50$ \\
\hline 009 & 102.99 & 100.00 & $95.00-107.50$ \\
\hline
\end{tabular}




\section{DISCUSSION}

This study evaluates the different brands of vitamin C (ascorbic acid) in Freetown using the following methods: thin layer chromatography test, uniformity of dosage unit, assay to determine the content of active pharmaceutical ingredients in the pharmaceutical tablet, colourimetric method, friability, and disintegration test [8].

The sample profile in table 1 describes the different brands of Vitamin C based on packaging, manufacturing country, storage condition, and the strength of ascorbic acid used. The uniformity of the dosage unit [8] for determining the consistency in the amount of ascorbic acid for each brand of vitamin C. Sample 2 was outside the required limit for the first assessment but was within the accepted limit for the second assessment. Therefore, all the samples in this study met the deviation and acceptance values as per the British Pharmacopoeia 2018.

The retention factor (Rf) of 0.7 for identification of pure vitamin $\mathrm{C}$ showed that all the different brands of vitamin $\mathrm{C}$ contained ascorbic acid. A study conducted in India also used the retention factor as a method for the identification of active ingredients [9]. In addition, a 2008 study conducted in Nigeria also showed that pure ascorbic acid or vitamin C brands had an Rf value of 0.7 [2].

Friability test for all the samples gave a weight loss of $<1 \%$ revealing that all the samples complied with the BP (2018) specification and that these brands can withstand abrasion without loss of integrity. This friability result is similar to a study conducted in Bangladesh in which most of the samples passed the standard limit of friability (Not more than 1\%) [10].

The disintegration test (non-official method) done on the four brands of non-chewable tablets showed that three of the brands complied with the specification of less than $15 \mathrm{~min}$ for disintegration time while one of the brands failed the disintegration test. The disintegration test does not apply to chewable tablets BP 2018 [7]. The ability of the three brands to disintegrate within this time indicates that these tablets can break down in the gastrointestinal tract and release their content into the systemic circulation. This result is similar to a study conducted in Nigeria for determining the disintegration rates in which disintegration time ranged from 0.32 to $24.03 \mathrm{~min}$, and all the disintegration times were within the $\mathrm{BP}$ official limit of $30 \mathrm{~min}$ [11].

The assay results for ascorbic acid using titrimetric and colourimetric methods for all the samples were comparable. The results showed that the titration value and colourimetric value for the ascorbic acid were consistent, indicating that each technique is appropriate for determining ascorbic acid. This result means that there was little or no interference of the excipient on the assay procedure [12]. Seven out of the nine brands were within the official titration specification of $95.0-107.50 \%$ BP (2018). One sample had more than the required active ingredient, possibly because of the addition of overages to vitamins by most manufacturers [13]. One brand failed both titrimetric and colourimetric analysis, maybe due to poor storage at the pharmaceutical outlet or poor handling during transportation from manufacturer to the point of sale or use. Research evidence in Bangladesh showed poor pharmaceutical practices in pharmacies of Bangladesh and confirmed that the regulatory authority has a vital role to play in shaping the behaviour of pharmacies [14].

This study has shown a need for functional evaluation of the quality of drugs in the supply chain through robust pre-and post-market surveillance measures to identify substandard and deteriorated drugs. Furthermore, in ascertaining the quality of different brands of medicine, assay for active constituents should be combined with assessment of other pharmaceutical parameters that include storage conditions and the suitability of the facilities handling the products and personnel.

Our study did not determine the storage condition of the different pharmaceutical outlets. However, this study provided information on the quality of vitamin $\mathrm{C}$ and their registration status despite this limitation. It also showed the need for wide-scale post-market research to understand the effect of environmental conditions on drugs and their drug deterioration in the supply chain in different parts of the country.

\section{CONCLUSION}

Our study confirmed that one of the nine vitamin C products assessed was unregistered. Also, our findings showed that one of the nine registered samples did not contain the required content of Vitamin C. Our results emphasised the need for pharmaceutical wholesalers and retailers to follow the shelf-life storage recommendations of the manufacturer. The study provides good insight into the importance of conducting routine quality evaluation through post-market surveillance and the need to ascertain good pharmaceutical practice, including good storage and identification of potential substandard and counterfeit medications.

\section{ACKNOWLEDGEMENT}

The authors express their sincere thanks and appreciation to all those who participated in this research. Their participation helped to understand and provide solutions to evaluating the quality of different brands of vitamin C in Sierra Leone.

We express our thanks and appreciation to the Laboratory and all staff of the Pharmacy Board of Sierra Leone. We are particularly indebted to Edward E. Okiako, who assisted with experimental analysis at the National Pharmaceutical Quality Control laboratory of the Pharmacy Board of Sierra Leone.

\section{FUNDING}

The funding for this research was through private funding provided by the researchers of this study.

\section{AUTHORS CONTRIBUTIONS}

All authors have read and approved the manuscript. ML and AFM developed the concept and proposal of the study. ML, EBSC, MS guided the research methods.

ML and AMF analysed the dataset while ML, EBSC, ATK, MS, MB, JPK, and WCNJ provided expert reviews. AMF collected data, and ML and AMF prepared the write-up. ML, EBSC, JA, MB and MS finalised the assessment of the study.

\section{CONFLICT OF INTERESTS}

The authors declare no competing interests whatsoever.

\section{REFERENCES}

1. May JM, Harrison FE. Role of vitamin C in the function of the vascular endothelium. Antioxidants Redox Signaling 2013;10:2068-83.

2. Soyinka J, Faleye F, Adetogun G. Quality evaluation of some brands of vitamin C preparations. Nig J Pharm Res 2008;7:12-7.

3. Lawson G, Ogwu J, Tanna S. Quantitative screening of the pharmaceutical ingredient for the rapid identification of substandard and falsified medicines using reflectance infrared spectroscopy. PloS One 2018;13:8.

4. Pisoschi AM. Vitamin C as contributor to the total antioxidant capacity-importance, occurrence, methods of determination. Biochem Anal Biochem 2013;2:4.

5. Ajibola VO, Babatunde OA, Suleiman S. The effect of storage method on the vitamin $C$ content in some tropical fruit juices. Trends Appl Sci Res 2009;4:79-84.

6. Du B, Daniels VR, Vaksman Z, Boyd JL, Crady C, Putcha L. Evaluation of physical and chemical changes in pharmaceuticals flown on space missions. AAPS J 2011;13:299-308.

7. British Pharmacopoeia, Wikipedia. Available from: https://en.wikipedia org/w/index.php?title=British_ Pharmacopoeiaandoldid $=999093812$. [Last accessed on 20 Feb 2021]

8. Walode SG, Chaudhari HK, Saraswat MS, Kasture AV, Wadodkar SG. Validated high-performance thin layer chromatographic determination and content uniformity test for rosiglitazone in tablets. Indian J Pharm Sci 2010;72:249-52. 
9. Patil V, Kale S, Sahare P, Vithaldes S. Simultaneous HPTLC analysis of Gliclazide and Metformin hydrochloride in bulk and tablet dosage form. JSIR 2014;3:325-31.

10. Wahid S, Hossain M. A comparative study on quality analysis on marketed vitamin $\mathrm{C}$ (ascorbic acid) tablets of different brands available in Bangladesh. World J Pharm Res 2019;9:146-57.

11. Musa H, Sule YZ, Gwarzo MS. Assessment of physicochemical properties of metronidazole tablets marketed in Zaria, Nigeria. Int J Pharm Pharm Sci 2011;3:27-9.
12. Aderibigbe SA, Adegoke OA, Idowu OS. A new colorimetric method for the determination of nifedipine tablets by derivatization using 4-carboxyl-2,6-dinitrobenzene diazonium ion. Int J Ind Chem 2012;3:3-5.

13. Yoo SJ, Walfish SL, Atwater JB, Giancaspro G, Sarma N. Factors to consider in setting adequate overages of vitamins and minerals in dietary supplements. Pharmacopeial Forum 2016;42:1-12.

14. Miller R, Goodman C. Performance of retail pharmacies in lowand middle-income Asian settings: a systematic review. Health Policy Plan 2016;31:940-53. 